\title{
Microbiological and Organoleptic Quality Characteristics of Laboratory Produced Date Fruit- based Kunun-zaki
}

\author{
O. J. Egbere, C. E. Odu, I. A. Onyimba, A. C. Ngene, A. E. Yusuf, A. O. Ogaji, \\ M. M. Dashen, W. N. Hemen, and E. E. Entonu
}

\section{ABSTRACT}

In the quest to produce an acceptable local beverage that could serve as an alternative variety to kunun-zaki for many millions of Nigerians who take the cereal-based beverage as their most preferred and affordable drink a study was undertaken to assess the microbial and sensory quality attributes of laboratory-produced Date fruit-based kunun-zaki. Different blends of dry date fruits (Phoenix dactylifera) and sorghum (Sorghum bicolor) formulated as follows; F1 (100:0), F2 (70:30), F3 (50:50), and F4 (30:70\%) of date fruits/sorghum were soaked overnight in water, drained and were wet-milled with ginger and cloves using an equal volume of sterile water, F5 (0:100) was market (Control) sample. The microbial succession study included the identification of organisms at various critical stages of the production of the beverage. The results of the study showed the mean $\mathrm{pH}$, and TTA (\%) values for the respective formulated Kunun-dabino product were F1 (4.87 and 0.3870$)$, F2 (4.66 and 0.4508$)$, F3 (4.29 and 0.4600), F4 (4.04 and 0.4690$)$, F5/Control (4.32 and 0.4589$)$ respectively. The mean Total bacterial, coliform and fungal loads of the four experimental products were $2.58 \times 104$, NIL, and $3.56 \times 103 \mathrm{CFU} / \mathrm{ml}$ respectively which fall within W.H.O's recommended standards for ready-to-eat foods. Species of Bacillus, Enterobacter, Shigella, Lactobacillus, Aspergillus, Penicillium Mucur, and Candida were present at the initial production stage while Bacillus and Lactobacillus species persisted right through to the final stage of production. The results of the sensory evaluation showed that while F1 was the least liked, F3 was significantly preferred over the other samples (P $<0.05$ ). The study has shown that 'Kunun dabino' produced under the laboratory conditions in this study provides a new brand of beverage that is both microbiologically safe and organoleptically more acceptable to taste panelists.

Keywords: Date fruit, Indigenous fermented foods, Kunun-dabino, Kununzaki, Microbial succession.
Published Online: June 30, 2021

ISSN: $2684-5199$

DOI: 10.24018 /ejbio.2021.2.3.193

\section{O. J. Egbere*}

Department of Microbiology, Faculty of Natural Sciences, University of Jos, Nigeria. (e-mail: egbereo@yahoo.com) C. E. Odu

Department of Biological Sciences, Faculty of Natural Sciences, University of Maiduguri, Nigeria.

I. A. Onyimba

Department of Science Laboratory

Technology, Faculty of Natural

Sciences, University of Jos, Nigeria.

A. C. Ngene

Department of Microbiology, College of Natural Sciences, Michael Okpara University of Agriculture, Umudike, Nigeria.

\section{A. E. Yusuf}

Department of Microbiology, Faculty of Natural Sciences, University of Jos, Nigeria.

A. O. Ogaji

Department of Microbiology, Faculty of Natural Sciences, University of Jos, Nigeria.

M. M. Dashen

Department of Microbiology, Faculty of Natural Sciences, University of Jos, Nigeria.

W. N. Hemen

Fidei Polytechnic, Gboko, Nigeria.

E. E. Entonu

Department of Microbiology, Faculty of Natural Sciences, University of Jos, Nigeria.

*Corresponding Author

\section{INTRODUCTION}

'Kunu' is a Hausa generic name for all kinds of cerealbased beverages with specifications normally attached to denote the source from which it is made or its sensory attributes. Hence, kunun-zaki means "sweet kunu" normally prepared from cereals [1] while 'kunun-dabino' refers to that made from date fruits (Phoenix dactylifera).

Kunun-zaki is a traditionally cereal-based, non-alcoholic beverage that originated in the northern part of Nigeria and has received wide acceptance among people of other parts of the country as well as neighboring North African countries of Nigeria. Its consumption cuts across all social classes and ages [2]. This is because of its high thirst-quenching and energy-giving attributes. In the traditional processing of kunun-zaki, Sweet-Potatoes (Ipomoea batatas), Ginger (Zingiber officinale), Cloves (Eugenia aromatica), and black pepper (Piper guinenses) are often used as additional ingredients to the basic cereal grain which could be Sorghum, Millet or Maize [3]. Sweet potatoes are used to add sweetness and body to the drink, while ginger, cloves, and black pepper are added in desired combinations for flavoring. 
Unfortunately, the art of production of this food is largely crude, time-consuming, and does not allow for increased production to meet increasing demand [4], [5].

The date is gotten from the date palm (Pheonix dactylifera L.) which belongs to the family of Arecaccae, which is believed to have originated around Iraq and have possibly been cultivated as early as $4000 \mathrm{BC}$, from where it spread to the rest of the world [6]. Date fruit contains a high percentage of carbohydrates with total sugars of about $44-88 \%$ and is known to be packed with essential nutrients, including minerals and vitamins, required for growth and development and overall well-being. In addition to being eaten out-ofhand, dates have been employed as natural sweeteners and used in sweetening a variety of drinks [7], [8].

The works of [7], [9], [10] showed that dates are among the popular natural sweeteners because of their antioxidant content. Their results showed that date fruits have higher nutritive value than sweet potatoes in almost all the nutrients studied. Date fruits also have a very low content of sodium (1 $\mathrm{mg}$ ) and higher content of potassium (696 mg) per $100 \mathrm{~g}$ of date fruit than sweet potatoes having sodium and potassium contents of $55 \mathrm{mg}$ and $337 \mathrm{mg}$ respectively per $100 \mathrm{~g}$ of sweet potatoes. The use of dates will also go a long way to improve the nutritive value of the beverage as well as make it more suitable for persons suffering from hypertension because of its low sodium content.

As a natural sweetener, dates for Kunun-zaki beverages will also pose a more acceptable sweetening power to the beverage [7], [11], [12]. This study aims at incorporating Date fruit as a supplement/alternative sweetener to the conventionally use of sweet potato to kunun-zaki with the objectives of understudying the fermentation rate, microbial quality, and organoleptic acceptability of the beverage.

\section{MATERIALS AND Methods}

\section{A. Sample Collection}

Samples of dry date fruits, red variety of Guinea corn (Sorghum bicolour), cloves, ginger, and a cereal (Sorghum) based kunun zaki samples were purchased from the Central Terminus market in Jos metropolis and taken to the Food Microbiology section of the Central Microbiology Laboratory of the Department of Microbiology in the University of Jos, Nigeria.

\section{B. Production of Date Fruit-based Kunun-zaki}

Four (4) samples of date fruit-based kunun-zaki were produced using various combinations of Date fruit to Sorghum ratios of Date fruit to Sorghum grains as follows respectively: F1 (100:00), F2 (70:30), F3 (50:50), and F4 (30:70) where F1 to F4 are formulations and their ratios in respective parenthesis.

The various experimental samples of Kunu as outlined in the formulation above (F1 to F4) were prepared following the procedure adopted by [1] with some slight modifications. The various raw materials in batches were thoroughly washed and rinsed three times using sterile water and then soaked for 12 hours (overnight). The soaked grains were drained in a sterile plastic sieve for 30 minutes and then wet-milled using a sterile laboratory blender to obtain a very soft paste.

The ground paste of each batch was divided into two halves. One half was kept cold while hot boiling water was poured into the second half and stirred vigorously to obtain a thick gelatinized mass. The hot paste was then mixed with the cold portion to obtain a free-flowing pre-cooked mixture that was left slightly covered overnight to undergo spontaneous fermentation. The fermented slurry was filtered through a sterile sieve mesh muslin cloth and then the filtrate is bottled in sterile plastic containers and labeled as Kunu. The flow chart for the production is shown below and the various point of sampling is indicated in asterisks.

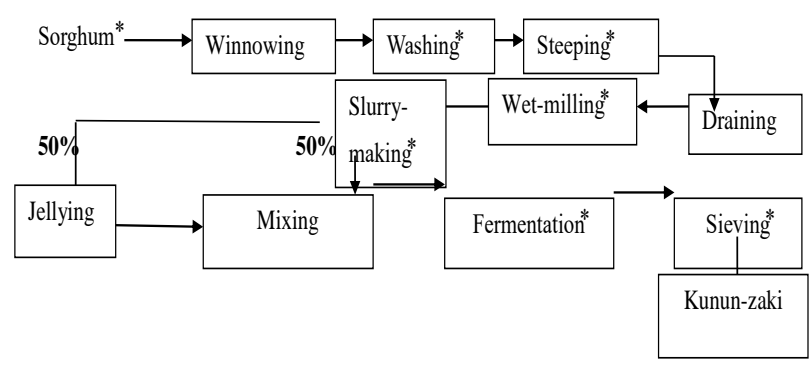

Fig. 1. Flow chat for the production of kunun-zaki [1]

\section{Asepsis}

The laboratory production of kunun and different media/samples used for microbial analysis were prepared under highly aseptic conditions. The glass pipettes, bottles, test tubes, glass Petri plates, incubator workbench were sterilized before use. The windows were closed, a face mask was put on, hand gloves were worn, and a clean laboratory coat was also worn during any experimental procedure involving kunun production and inoculation of the microorganisms.

\section{Preparation of Media}

The different media used for microbial analysis were prepared in conformance to the manufacturer's specifications and instructions. Nutrient agar for total plate count, MacConkey agar for the coliform count, and Sabouraud dextrose agar for fungal load respectively.

\section{E. Enumeration of Microorganism at Various Stages of Date Fruit Based Kunun-zaki}

Microorganisms from each sample of the four preparations were enumerated using a ten-fold serial dilution/Pour plating technique. Tenfold serial dilution using $1 \mathrm{ml}$ of stock solution of each sample was prepared up to the 5 th power and $1 \mathrm{ml}$ of each diluent was pour plated onto Petri dishes before $25 \mathrm{ml}$ of lukewarm molten medium is poured and gently rocked to ensure even spread of the mixture in the plates [13]. Samples on Nutrient agar and MacConkey agar plates were incubated for 24 hours at $37^{\circ} \mathrm{C}$, while those on Sabouraud dextrose agar plates were incubated for 5 days at $25{ }^{\circ} \mathrm{C}$. A Digital illuminated colony counter was used to count the colonies of the isolates. Distinct colonies that were formed on the agar plates were counted, averaged, and expressed as colonyforming units per $\mathrm{ml}(\mathrm{CFU} / \mathrm{ml})$. Pure cultures for identification of each isolate were made by streaking the individual colony on a suitable medium and incubating appropriately and then maintained in an agar slant contained in MacCartney bottles [13]. 


\section{F. Identification of Microbial Isolates}

\section{Macroscopic examination of the isolates}

Colonies of bacteria isolates were examined macroscopically for morphological characteristics, including size, shape, color, margin, elevation consistency, and hemolysis according to descriptions by [14]. The fungal isolates were examined based on distinctive macroscopic features (rate of growth, pigmentation, texture, and colony morphology) and microscopic features such as the nature of mycelium, hyphae, conidia, sporangia, and sporangiophores regarding pictures in fungi in the Compendium Atlas of Soil Fungi [14].

2. Microscopic examination and biochemical characterization of bacterial isolates

To identify the organisms to species levels, various pure bacterial isolates were subjected to the microscopic examination of gram-stained colonies as well as the determination of biochemical characteristics of the isolates as described by [15].

\section{G. Physico-chemical Analysis}

\section{1. $p H$ Determination}

The $\mathrm{pH}$ of kunun-zaki was determined using a $\mathrm{pH}$ meter (WPA pH Meter, India). The $\mathrm{pH}$ meter was first standardized with a buffer solution of $\mathrm{pH} 4.0$ and 7.O (BDH, England). The $\mathrm{pH}$ value of the samples was determined by dipping or immersing the probe of the meter into and a beaker containing $100 \mathrm{ml}$ of kunun-zaki.

\section{Total Titratable acidity (as lactic acid)}

$10 \mathrm{ml}$ of date fruit-based kunun-zaki was measured into a $250 \mathrm{ml}$ conical flask and four drops of phenolphthalein indicator were added and were titrated with the standard $0.1 \mathrm{~N}$ $\mathrm{NaOH}$ to the distinct faint pink point. The total titratable acidity was expressed as lactic acid $(\mathrm{g} / 100 \mathrm{ml})$ as described by [16].

$$
\begin{aligned}
& \text { Calculation: } \% T . T . A= \\
& =\frac{\text { Volume of base } x \text { normality of base } \times 0.0090018 \times 100}{\text { Volume of sample used }}
\end{aligned}
$$

0.0090018 is the mill-equivalent weight of lactic acid.

\section{H. Sensory Evaluation}

A five (5) point hedonic scaled Questionnaire was designed to collect data in the evaluation of date fruit-based kunun-zaki in comparison with control (sorghum-based kunun-zaki) using sensory parameters such as taste, aroma, color, consistency, and overall acceptability [17]. The taste panelist board is composed of ten (10) persons who are conversant with the consumption of kunun-zaki. The rank scored data obtained from the Sensory evaluation were subjected to statistical analysis to determine the significant difference in the means of each value of sensory parameters evaluated.

\section{RESULTS}

The results of the physicochemical parameters of the various kunun-zaki samples are shown in Table I. All the samples were slightly acidic with a pH range of 4.04 to 4.87 . The sample F4 (30\% Date: 70\% sorghum) had the lowest $\mathrm{pH}$ value of 4.04 while that of F1 (100\% Date) had the highest value of 4.87. The sample F5 (control) had a pH value of 4.32 which was not significantly higher $(\mathrm{P}<0.05)$ than that of $\mathrm{F} 3$ (4.29) made with $50 \%$ incorporation of date fruits. The values of Titratable acidity (TTA) of the samples F2 (70\% Date: $30 \%$ Sorghum), F3 (1:1), F4 (3:7), and F5 (control) were statistically similar $(\mathrm{P}>0.05)$ and were significantly higher than that of F1.

The values of the sedimentation rate (Table I) also showed a significant increase $(\mathrm{P}<0.05)$ in the sedimentation rate of the samples with an increase in date fruit incorporation. Among the samples made with date fruit, F5 (Control) had the highest sedimentation value $(3.2667 \mathrm{ml} / \mathrm{min})$ while the lowest value was that of F4 $(2.2667 \mathrm{ml} / \mathrm{min})$. However, there was no significant difference $(\mathrm{P}>0.05)$ between the sedimentation rate of the sample made with sweet potatoes, and that made with $50 \%$ incorporation of date fruits (F3).

The results of the study on organoleptic evaluation showed that generally, there were no significant differences in the mean ranked scores of samples based on color for samples F3, F4 and F5 while the means of the tastes of the samples varied, with the most preferred being sample F4.

The aroma of sample F5 (control) was, however, most preferred. Generally, the mean scores of the samples showed that sample F4 was most preferred based on taste, sweetness, mouthfeel, and general acceptability at a 5\% level of probability.

The results of the percentage reduction in microbial loads (Total plate count, Coliform, and Fungal Counts) of raw materials after washing in sterile water for (3) rinses are shown in Table III and IV. The results showed that there was a decrease in microbial load after proper rinsing for all the raw material samples.

3 . The results of the morphological, microscopic, and biochemical characteristics of bacterial isolates associated with the production of Date fruit-based kunun-zaki are shown in Table V. Eleven bacterial genera were isolated and characterized. They were characterized as Pseudomonas spp, Klebsiella spp, Staphylococcus spp, Proteus spp, Bacillus spp, Streptococcus spp, Micrococcus spp, Enterobacter spp, E. coli, Shigella spp, Lactobacillus spp. Mold and yeast isolates were four and two respectively, and they were identified as Penicillium spp, Mucor spp, Aspergillus spp, and Rhizopus spp, and Saccharomyces spp, and Candida spp. as shown in Table VI. The Mean values of Sensory Evaluation of Date fruit-based kununzaki checked were color, taste, aroma, sweetness, mouthfeel. The overall assessment indicates that sample $\mathrm{F} 1$ has the least with a mean value of $2.5 \pm 0.707$ a, followed by F3 with $3.4 \pm 0.516 \mathrm{~b}, \mathrm{~F} 2, \mathrm{~F} 5$, and F4, having $3.5 \pm 0.483 \mathrm{~b}, 3.5 \pm 0.527 \mathrm{~b}$, and $4.4 \pm 0.516 \mathrm{c}$. as shown in Table VII.

TABLE I: PHYSICOCHEMICAL PARAMETERS OF THE LABORATORY PRODUCED DATE FRUIT-BASED KUNUN-ZAKI SAMPLES

\begin{tabular}{cccc}
\multicolumn{4}{c}{ PRODUCED DATE FRUIT-BASED KUNUN-ZAKI SAMPLES } \\
\hline Samples & $\mathrm{pH}$ & TTA $(\%)$ & $\begin{array}{c}\text { Sedimentation } \\
\text { Rate }(\mathrm{ml} / \mathrm{min})\end{array}$ \\
\hline F1 & 4.87 & 0.387 & 3.2667 \\
F2 & 4.66 & 0.4608 & 32,333 \\
F3 & 4.29 & 0.46 & 3.067 \\
F4 & 4.04 & 0.459 & 2.2667 \\
F5/Control & 4.32 & 0.4589 & 3.2667 \\
\hline
\end{tabular}

$\mathrm{TTA}=$ Total Titratable Acid 
European Journal of Biology and Biotechnology www.ejbio.org

TABLE II: MicRoBiAL LOADS OF THE RAW MATERIALS USED IN THE PRODUCTION OF DATE Fruit BASED KUNUN-ZAKI (KunUN-DABINO)

\begin{tabular}{cccc}
\hline Raw Materials & $\begin{array}{c}\text { Total Viable } \\
\text { count }(\mathrm{cfu} / \mathrm{ml})\end{array}$ & $\begin{array}{c}\text { Coliform } \\
\text { count } \\
(\mathrm{cfu} / \mathrm{ml})\end{array}$ & $\begin{array}{c}\text { Fungal count } \\
(\mathrm{cfu} / \mathrm{ml})\end{array}$ \\
\hline Unwashed Date fruit & $1.15 \times 10^{6}$ & $1.68 \times 10^{6}$ & $2.68 \times 10^{6}$ \\
Washed Date fruit & $1.04 \times 10^{6}$ & $1.22 \times 10^{6}$ & $1.90 \times 10^{6}$ \\
Unwashed Sorghum & $1.55 \times 10^{6}$ & $1.40 \times 10^{6}$ & $2.03 \times 10^{6}$ \\
Washed Sorghum & $0.98 \times 10^{6}$ & $0.26 \times 10^{6}$ & $0.710 \times 10^{6}$ \\
Unwashed Ginger & $0.99 \times 10^{6}$ & $0.03 \times 10^{6}$ & $1.21 \times 10^{6}$ \\
Washed Ginger & $0.59 \times 10^{5}$ & $\mathrm{NIL}$ & $1.10 \times 10^{6}$ \\
Unwashed Black pepper & $2.3 \times 10^{5}$ & $2.72 \times 10^{6}$ & $1.00 \times 10^{6}$ \\
\hline
\end{tabular}

Values of three counts recorded as mean

$\mathrm{NIL}=$ Absent.

$\mathrm{NP}=$ Not Plated.

TABLE III: PERCENTAGE REDUCTION IN MicRobial LOADS OF RAW

MATERIALS AFTER WASHING IN STERILE WATER (FOR 3 RINSES)

\begin{tabular}{|c|c|c|c|}
\hline \multirow{2}{*}{$\begin{array}{l}\text { Raw } \\
\text { Materials }\end{array}$} & $\begin{array}{l}\text { Total Viable } \\
\text { Count }\end{array}$ & Coliform count & Fungal count \\
\hline & (\% Decrease) & (\% Decrease) & (\% Decrease) \\
\hline Date fruit & 9.57 & 27.38 & 29.1 \\
\hline Sorghum & 36.77 & 81.42 & 65.02 \\
\hline Ginger & 40.4 & 100 & 9.09 \\
\hline $\begin{array}{l}\text { Black } \\
\text { pepper }\end{array}$ & 79.09 & 31.25 & 60.00 \\
\hline Clove & 17.52 & 15.24 & NIL \\
\hline \multicolumn{4}{|c|}{$\begin{array}{l}\text { TABLE IV: BACTERIA/ FUNGI ISOLATED FROM RAW MATERIALS USED IN } \\
\text { THE PRODUCTION OF DATE FRUIT BASED KUNUN-ZAKI } \\
\end{array}$} \\
\hline Raw materials & \multicolumn{2}{|c|}{ Bacterial Isolates } & Fungal Isolates \\
\hline Sorghum & \multicolumn{2}{|c|}{$\begin{array}{l}\text { Lactobacillus spp } \\
\text { Shigella } \mathrm{spp}\end{array}$} & $\begin{array}{c}\text { Aspergillus niger, } \\
\text { Mucur } \mathrm{spp}\end{array}$ \\
\hline Date Fruit & $\begin{array}{l}\text { Pseud } \\
\text { Strep }\end{array}$ & $\begin{array}{l}\text { as spp, } \\
\text { cus spp }\end{array}$ & $\begin{array}{l}\text { Rhizopus spp, } \\
\text { Penicillium spp }\end{array}$ \\
\hline Ginger & $\begin{array}{c}\text { Klebsiel } \\
\text { Staphy }\end{array}$ & $\begin{array}{l}\text { Bacillus } \\
\text { cus spp }\end{array}$ & Penicillium spp \\
\hline Black Pepper & \multicolumn{2}{|c|}{ Bacillus spp } & $\begin{array}{l}\text { Trichophyton spp, } \\
\text { Penicillium spp }\end{array}$ \\
\hline Clove & \multicolumn{2}{|c|}{$\begin{array}{l}\text { Staphylococcus spp, } \\
\text { Micrococcus spp }\end{array}$} & Trichophyton spp, \\
\hline
\end{tabular}

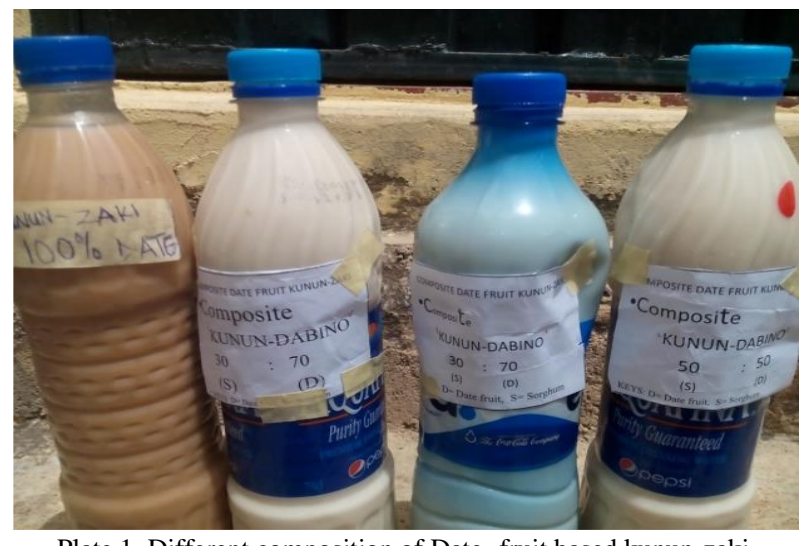

Plate 1. Different composition of Date- fruit based kunun-zaki.

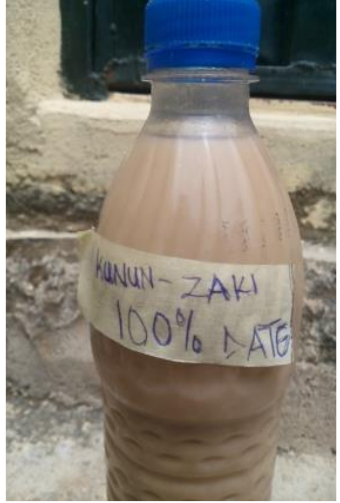

Plate 2. 100\% Kunun-Dabino (Date fruits).

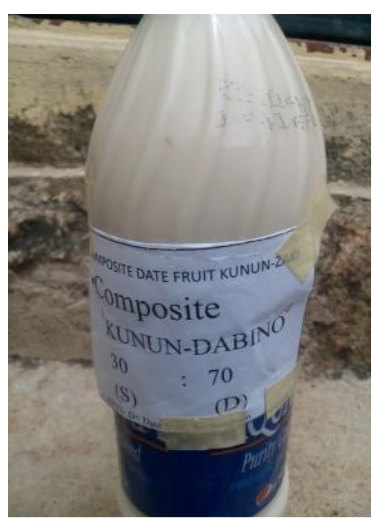

Plate 3. 70\% Kunun-Dabino (Date fruits).
TABLE V: CHANGES IN THE Microbial LOAD OF SAMPLES TAKEN DURING THE PRODUCTION OF DATE FRUIT BASED KUNUN-ZAKI (KUNUN-DABINO)

\begin{tabular}{|c|c|c|c|c|}
\hline $\begin{array}{l}\text { Production } \\
\text { Stages }\end{array}$ & $\begin{array}{c}\text { Various } \\
\text { samples/control }\end{array}$ & Bacteria/cfu & $\begin{array}{c}\text { Total } \\
\text { Coliforms }\end{array}$ & Fungi \\
\hline \multirow[t]{4}{*}{ Raw Materials } & $\mathrm{F} 1$ & $1.40 \times 10^{6}$ & $1.00 \times 10^{5}$ & $6.0 \times 10^{5}$ \\
\hline & $\mathrm{F} 2$ & $1.37 \times 10^{6}$ & NIL & $9.0 \times 10^{5}$ \\
\hline & F3 & $1.19 \times 10^{6}$ & $1.10 \times 10^{5}$ & $6.6 \times 10^{5}$ \\
\hline & $\mathrm{F} 4$ & $1.20 \times 10^{6}$ & NIL & NIL \\
\hline \multirow[t]{4}{*}{ After steeping } & $\mathrm{F} 1$ & $1.63 \times 10^{6}$ & NIL & $6.7 \times 10^{5}$ \\
\hline & $\mathrm{F} 2$ & $0.60 \times 10^{6}$ & NIL & $8.2 \times 10^{5}$ \\
\hline & $\mathrm{F} 3$ & $1.30 \times 10^{6}$ & NIL & $1.01 \times 10^{6}$ \\
\hline & $\mathrm{F} 4$ & $1.21 \times 10^{6}$ & NIL & $7.7 \times 10^{5}$ \\
\hline \multirow[t]{4}{*}{ Wet milling } & $\mathrm{F} 1$ & $1.83 \times 10^{6}$ & $1.01 \times 10^{5}$ & $1.11 \times 10^{5}$ \\
\hline & $\mathrm{F} 2$ & $1.06 \times 10^{6}$ & & $1.51 \times 10^{6}$ \\
\hline & $\mathrm{F} 3$ & $1.48 \times 10^{6}$ & NIL & $1.90 \times 10^{5}$ \\
\hline & F4 & $7.80 \times 10^{5}$ & NIL & $3.10 \times 10^{5}$ \\
\hline After & $\mathrm{F} 1$ & $1.74 \times 10^{6}$ & NIL & $1.43 \times 10^{6}$ \\
\hline \multirow[t]{3}{*}{ Pregellatinization } & $\mathrm{F} 2$ & $1.41 \times 10^{6}$ & NIL & $1.0 \times 10^{6}$ \\
\hline & F3 & $1.00 \times 10^{6}$ & NILS & $2.10 \times 10^{6}$ \\
\hline & $\mathrm{F} 4$ & $1.89 \times 10^{6}$ & NIL & $1.04 \times 10^{6}$ \\
\hline \multicolumn{5}{|l|}{ After mixing of } \\
\hline $\begin{array}{l}\text { pregellatinized } \\
\text { paste with raw } \\
\text { slurry (prior }\end{array}$ & $\mathrm{F} 1$ & $1.12 \times 10^{6}$ & NIL & $1.20 \times 10^{6}$ \\
\hline \multirow[t]{3}{*}{ to fermentation) } & $\mathrm{F} 2$ & $1.28 \times 10^{6}$ & NIL & $1.03 \times 10^{6}$ \\
\hline & F3 & $1.15 \times 10^{6}$ & NIL & $1.30 \times 10^{6}$ \\
\hline & $\mathrm{F} 4$ & $0.73 \times 10^{5}$ & NIL & $1.5 \times 10^{6}$ \\
\hline during & $\mathrm{F} 1$ & $1.15 \times 10^{6}$ & NIL & $7.9 \times 105^{6}$ \\
\hline fermentation & $\mathrm{F} 2$ & $1.31 \times 10^{6}$ & NIL & $1.09 \times 10^{6}$ \\
\hline \multirow[t]{2}{*}{ (4hrs) } & F3 & $0.90 \times 10^{6}$ & NIL & $1.0 \times 10^{6}$ \\
\hline & $\mathrm{F} 4$ & $1.03 \times 10^{6}$ & NIL & $1.0 \times 10^{6}$ \\
\hline During & $\mathrm{F} 1$ & $1.17 \times 10^{6}$ & NIL & $1.95 \times 10^{6}$ \\
\hline \multirow{3}{*}{$\begin{array}{l}\text { fermentation } \\
\qquad(8 \mathrm{hrs})\end{array}$} & $\mathrm{F} 2$ & $1.45 \times 10^{6}$ & NIL & $2.00 \times 10^{6}$ \\
\hline & F3 & $1.04 \times 10^{6}$ & NIL & $1.22 \times 10^{6}$ \\
\hline & $\mathrm{F} 4$ & $0.90 \times 10^{6}$ & NIL & $1.02 \times 10^{6}$ \\
\hline Finished Product & $\mathrm{F} 1$ & $1.53 \times 10^{4}$ & NIL & $1.36 \times 10^{3}$ \\
\hline (after 14hrs) and & $\mathrm{F} 2$ & $1.29 \times 10^{4}$ & NIL & $5.1 \times 10^{3}$ \\
\hline pasteurized at & $\mathrm{F} 3$ & $1.60 \times 10^{4}$ & NIL & $1.09 \times 10^{3}$ \\
\hline \multirow{2}{*}{$\begin{array}{l}70{ }^{\circ} \mathrm{C} \text { for } 15 \\
\text { minutes }\end{array}$} & F4 & $5.90 \times 10^{4}$ & NIL & $6.7 \times 105^{3}$ \\
\hline & F5 Control & $1.37 \times 10^{6}$ & $1.44 \times 10^{6}$ & $1.61 \times 10^{6}$ \\
\hline
\end{tabular}

Key: F1 -F3 are samples of kunun with ratios of Date fruit to Sorghum grains respectively. F1 (100:00), F2 (70:30), F3 (50:50), F4(30:70) and F5(0:100).

TABLE VII: MEAN VALUES OF SENSORY EVALUATION OF DATE FRUIT- BASED KUNUN-ZAKI

\begin{tabular}{ccccccc}
\hline \multirow{2}{*}{ Sample } & Colour & Taste & Aroma & Sweetness & Mouth feel & $\begin{array}{c}\text { Overall } \\
\text { Acceptability }\end{array}$ \\
\hline F1 & $2.3 \pm 0.483 \mathrm{a}$ & $3.3 \pm 0.483 \mathrm{a}$ & $1.3 \pm 0.483 \mathrm{a}$ & $4.1 \pm 0.568 \mathrm{a}$ & $3.6 \pm 0.516 \mathrm{a}$ & $2.5 \pm 0.707 \mathrm{a}$ \\
F2 & $3.2 \pm 0.633 \mathrm{~b}$ & $2.7 \pm 0.675 \mathrm{~b}$ & $2.6 \pm 0.516 \mathrm{~b}$ & $3.6 \pm 0.516 \mathrm{~b}$ & $3.3 \pm 0.675 \mathrm{a}$ & $3.5 \pm 0.483 \mathrm{~b}$ \\
F3 & $3.6 \pm 0.516 \mathrm{c}$ & $3.6 \pm 0.516 \mathrm{c}$ & $2.3 \pm 0.483 \mathrm{~b}$ & $4.0 \pm 0.471 \mathrm{a}$ & $2.4 \pm 0.516 \mathrm{~b}$ & $3.4 \pm 0.516 \mathrm{~b}$ \\
F4 & $3.5 \pm 0.527 \mathrm{c}$ & $4.5 \pm 0.527 \mathrm{~d}$ & $3.5 \pm 0.527 \mathrm{c}$ & $4.0 \pm 0.516 \mathrm{a}$ & $4.0 \pm 0.00 \mathrm{c}$ & $4.4 \pm 0.516 \mathrm{c}$ \\
F5 & $3.5 \pm 0.527 \mathrm{c}$ & $3.0 \pm 0.00 \mathrm{c}$ & $4.0 \pm 0.00 \mathrm{~d}$ & $3.5 \pm 0.527 \mathrm{~b}$ & $3.0 \pm 0.00 \mathrm{a}$ & $3.5 \pm 0.527 \mathrm{~b}$ \\
\hline
\end{tabular}

Key: F1 -F5 are samples of kunu with ratios of Date fruit to Sorghum grains respectively. F1 (100:00), F2 (70:30), F3 (50:50), F4 (30:70) and F5(0:100).

* Mean scores with the same superscript on the same column imply that there is no significant difference between them at $5 \%$ level of significance.

Hedonic scales: 1-not like at all 2-Like a little, 3-like moderately, 4-like a lot, 5-like extremely. 
TABLE VI: SUCCESSION OF MicroorganisMS ASSOCIATED WITH THE PRODUCTION OF DATE FRUIT BASED KUNUN-ZAKi (KUNUN-DABINO)

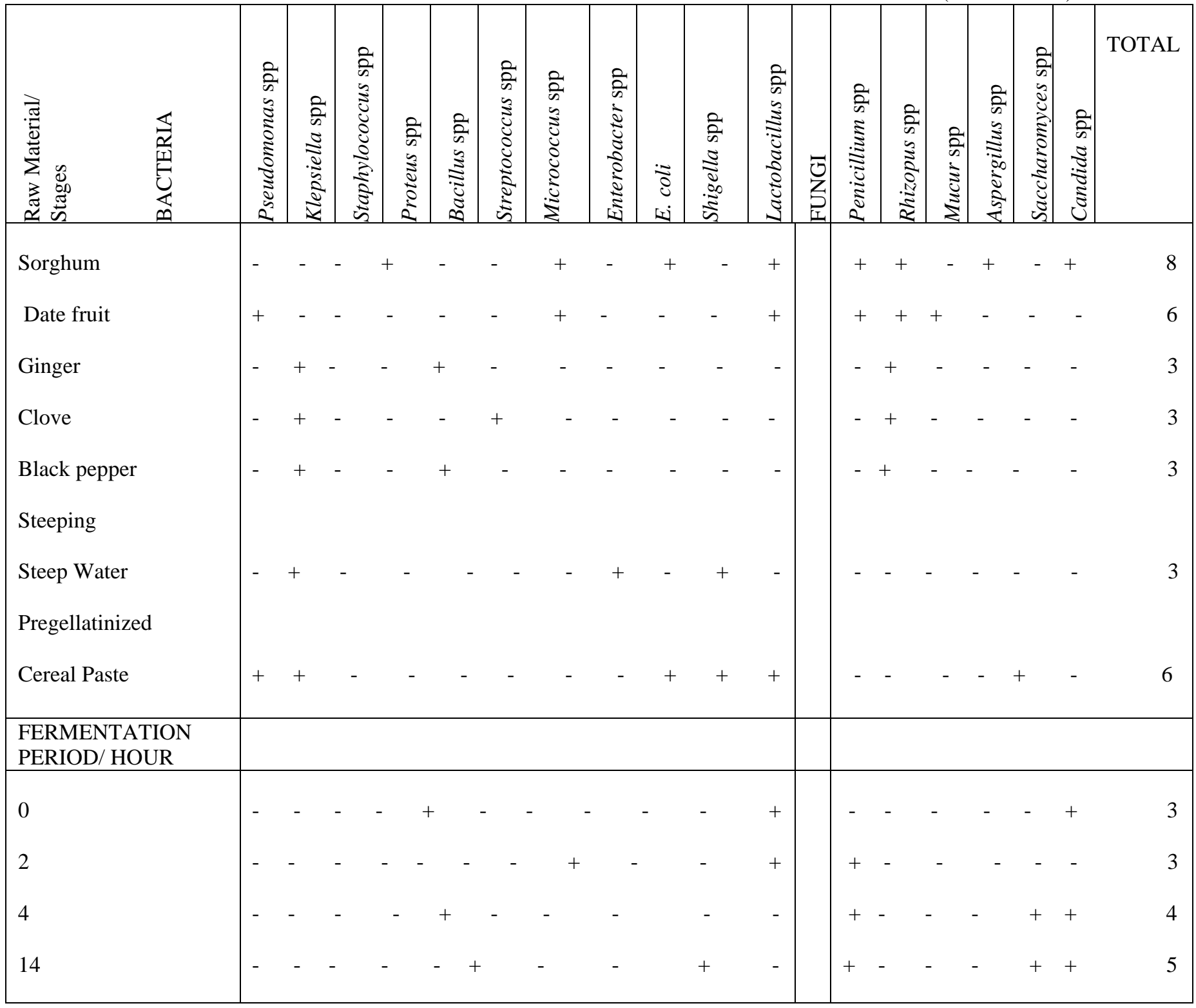

KEYS: - = Not present, += Present.

\section{DISCUSSION}

\section{A. Physicochemical Quality of Date Fruit-based Kunun-zaki}

The results of the physicochemical parameters of the various kunun-zaki samples indicate that all the samples were slightly acidic with a $\mathrm{pH}$ range of 4.04 to 4.87 and making this product fall into the category of acid-based food which supports the work of [18]. Sample F4 (30\% date: $70 \%$ sorghum) had the lowest $\mathrm{pH}$ value of 4.04 while that of F1 had the highest value of 4.87 . The sample F5 (control) had a $\mathrm{pH}$ value of 4.32 which was not significantly higher $(\mathrm{P}<0.05)$ than that of F3 (4.29) made with 50\% incorporation of date fruits. The lower value of F3 is an indication that date fruits may have more fermentable sugars than sorghum and other sweeteners such as sweet potatoes used conventionally in kunun-zaki production as supported by the work of $[19,1]$. Lactic acid bacteria have been found in the association among the major acid-producing/fermenting agents of kunun-zaki by [1], thereby resulting in the lowered $\mathrm{pH}$ values of kunun-zaki.

\section{B. Titratable Acidity and Sedimentation Rates of Kunun zaki}

The values of Titratable acidity (TTA) of the samples F2 (7:3 Date: Sorghum), F3 (1:1), F4 (3:7, and F5 (control) were statistically similar $(\mathrm{P}>0.05)$ and were significantly higher than that of the F1 (0.387). The low value of TTA for sample F1 (100\% date fruit) indicates poor fermentation which could have caused poor production of lactic acid. This invariably led to a higher $\mathrm{pH}$ value of this sample when compared with the other samples as reported in the work of [20].

Although there could have been more fermentable sugars in the $100 \%$ date fruit sample the fermentation rate was lower, this could be due to the lower presence of the lactic acid bacteria which were more in Sorghum.

The values of the sedimentation rate also showed a significant increase $(\mathrm{P}<0.05)$ in the sedimentation rate of the samples with an increase in date fruit incorporation. Among the samples made with date fruit, F1 $(100 \%$ date: $0 \%$ sorghum) had the highest sedimentation value $(3.2667 \mathrm{ml} / \mathrm{min})$ while the lowest value was that of F4 $(2.2667 \mathrm{ml} / \mathrm{min})$. There was no significant difference $(\mathrm{P}>$ $0.05)$ between the rate of sedimentation of the sample made 
with sweet potatoes and that made with $50 \%$ incorporation of date fruits F3 (50\% date : 50\% sorghum). The sedimentation rate is indicative of the surface tension created on the liquidsolid suspension. The higher the sedimentation rate the lower the surface tension created. Microbial metabolites secreted during fermentation such as acids, mucilaginous compounds, ketones, and aldehydes could influence the sedimentation rate. From this study, it was observed that the higher the acidity the lower the sedimentation rate, supporting the work of [20].

\section{Microbial Loads of the Kunun-zaki Samples}

The results of the means of the microbial loads (Total plate count, Coliform, and Fungal Counts) isolated from raw materials results indicate that the means of the total plate, coliform, and fungal count was high for Date fruit, Black pepper, and Date fruit while the values for Black pepper, Ginger and Black pepper were low for total plate count, coliform, and fungal counts respectively. The results of the percentage reduction in microbial loads (Total plate count, Coliform and Fungal Counts) of raw materials after washing in sterile water for (3) rinses show that washing the raw materials will reduce the microbial loads, which supports the research work of [21], [22]. The eleven bacterial genera isolated and characterized from the different production stages of date fruit-based kunun-zaki of the four laboratory preparations were composed of seven bacteria genera and four fungi, implying that the bacteria generally predominate in number than fungi basically because the food product is about $90 \%$ based on water, supports the report of [23]. The bacteria being Pseudomonas spp, Klebsiella spp, Staphylococcus spp, Proteus spp, Bacillus spp, Streptococcus spp, Micrococcus spp, Enterobacter spp, E. coli, Shigella spp, ad Lactobacillus spp. While the fungi were Penicillium spp, Mucor spp, Aspergillus spp, and Rhizopus spp, and Saccharomyces spp, and Candida spp, as supported by the work of [24], [25]. These organisms besides Pseudomonas spp were similar to those isolated and identified by [26] from sorghum-based kunun zaki. Pseudomonas spp must have emanated from the date fruit used as a raw material. Good enough, due to the increasing inimical acidity of the beverage Pseudomonas sp did not persist till the final stage the beverage was ready for drinking.

The presence of the three Lactic acid bacteria being Lactobacillus spp, Micrococcus spp, and Streptococcus spp as well as and Bacillus spp is not surprising as most of these thrive in medium rich in fermentable substrates like sugars, which often lead to the production of acids after fermentation as reported by [27], [26]. The absence of E. coli from the experimental samples could be due to the thorough washing and rinsing of the raw materials as well as the sterile water and strip aseptic procedures adopted in the production of the four experimental kunun zaki samples analyzed, supporting the work of [28]-[30]. In the same vein, the other coliforms got eliminated from the beverage due most likely to the presence of lactic acid and nisin secreted by the lactic acid bacteria present in the drink.

The presence of Escherichia coli in a control sample on the other hand is indicative of water (fecal) contamination and poor sanitary condition under which many locally processed beverages are exposed to. Strains of E. coli are known to be causative agents of food-borne gastroenteritis and bacterial diarrhea diseases. Their presence also could be attributed to the use of dirty containers, as well as the dirty environment where the Kunun-zaki samples were processed. The results support the findings of [31].

The presence of moulds (Penicillium spp, Mucor spp, Aspergillus spp, and Rhizopus spp) could be attributed to the indigenous association with the raw materials used and the environment in which the drink was prepared. The yeasts (Saccharomyces spp, and Candida spp) isolated in the preparations may be attributed to the acidic nature of the samples since it has been observed that yeasts are capable of utilizing organic acids from cereals [32]. These microbiological hazards identified (bacteria, coliform, and fungi) are associated with the raw materials/production. [34, $28,32]$ have reported that many of these organisms are pathogenic and occur naturally in the environment where foods are grown and processed.

Laboratory preparations still harbored some contaminants, though at a minimal level when compared with those of commercial preparations. The spices harbored undesirable organisms in some preparations, implying poor harvesting procedures and improper washing of the spices by the farmers and producers respectively. Laboratory preparation harbored no coliforms. In Laboratory preparation, the spices were thoroughly washed, hence no coliforms were isolated.

Unpeeled spices are usually used in Kunun zaki preparation before milling. Thus, this necessitates them to be thoroughly washed before milling. They are also known to be antimicrobials if devoid of dirt (accumulated soil or dust particles) and such dirt was removed in the Laboratory preparation of the beverage and hence got coliforms were eliminated from the entire samples [1], [26], [31].

\section{Organoleptic Quality}

The results of the sensory evaluation of the various samples indicate that sample F5 (control) scored lowest in all the parameters (taste, colour, aroma, mouth feel, general acceptability) studied. The sample F2 scored highest in taste, aroma, mouthfeel, and general acceptability. F1 was the least preferred in color among the kunu samples made with date fruits. This could be attributed to the darker color imparted to the beverage by this fruit at higher concentrations, confirming the report of [20]. Sample F4 with $70 \%$ sorghum had the highest score ranking on colour, implying that the colour of Sorghum had a positive effect on colour acceptability by panelists. Although the sweetness of the sample with $100 \%$ date fruit was most refereed, the preference was not significantly higher than that of F3 and F4, respectively. On a general note, the Kunun-zaki sample F4 was the most preferred followed by F5 and the least was F1 which was the control made without Date fruit. The inclusion of $30 \%$ date fruit has therefore given the blend that has the most acceptable ranking by taste panelist using the five multivariate organoleptic acceptability characteristics of colour, taste, sweetness, aroma, and mouthfeel.

\section{CONCLUSION}

The results obtained from the different analyses of the Date fruit-based-Kunu-zaki beverages produced with date fruits 
showed that the date fruit did not negatively alter the Physicochemical and sensory properties of the beverage, rather it improved the properties, making them more acceptable. It could be concluded that good manufacturing practices for Kunun zaki production involving the use of fresh non-moldy grains and spices, cooled boiled water for grain washing and steeping, sterile stainless steel containers, steam-washed grinder, and sterile screw-capped bottles for packaging applied at all stages of the production process in this study are effective and should be adopted in Kunun zaki production at larger scale levels.

The study has shown that the inclusion of $30 \%$ of date fruit to sorghum as raw material gave the most preferred and safe product blend of date-fruit based Kunun-zaki.

The findings from this research work show that date fruitbased kunun-zaki is safe for human consumption since the hazardous level of CFU (x105 cell/ml) for ready-to-eat food was not exceeded and contained no harmful organisms when properly processed.

\section{RECOMMENDATIONS}

Aseptic techniques if adopted in the processing of Kununzaki and kunun-dabino as described in this research can go a long way in enhancing the safety of the products for consumers. Considering the numerous benefits of date fruits to health and nutrition extensive and organized farming and its utilization for Kunun-zaki production is hereby advocated. Further work should be done on the glycemic index of date fruit-based Kunun-zaki to verify its suitability for the diabetics and Processors of Kunun-zaki should be encouraged to use date fruit to substitute for the use of sweet potato which could be reserved for other food and industrial uses.

\section{REFERENCES}

[1] Egbere, O.J., Onwuliri, F.C., Oyero, S.K., \& Henry, U.I. (2008). Accelerated fermentation process of kunun-zaki (A Nigerian NonAlcoholic Beverage). Adv. Sci. Technol. 2(1): 36-41.

[2] Amusa, N. A., \& Odunbaku, O. A. (2009). Microbiological and nutritional quality of hawked kunun (a sorghum based non-alcoholic beverage) widely consumed in Nigeria. Pakistan Journal of Nutrition, $8(1), 20-25$.

[3] Nahemiah, D., Bankole, O. S., Tswako, M., Nma-Usman, K. I., Hassan, H., \& Fati, K. I. (2014). Hazard Analysis Critical Control Points (HACCP) in the Production of Soy-kununZaki: A Traditional CerealBased Fermented Beverage of Nigeria. Am. J. Food Sci. Technol, 2(6), 196-202.

[4] Amadou, I., Gbadamosi, O. S., \& Le, G. W. (2011). Millet-based traditional processed foods and beverages-A review. Cereal Foods World, 56(3), 115.

[5] Achi, O. K., \& Ukwuru, M. (2015). Cereal-based fermented foods of Africa as functional foods. International Journal of Microbiology and Application, 2(4), 71-83.

[6] Chao, C. T., \& Krueger, R. R. (2007). The date palm (Phoenix dactylifera L.): overview of biology, uses, and cultivation. HortScience, 42(5), 1077-1082.

[7] Assirey, E. A. R. (2015). Nutritional composition of fruit of 10 date palm (Phoenix dactylifera L.) cultivars grown in Saudi Arabia. Journal of Taibah University for science, 9(1), 75-79.

[8] El-Sohaimy, S. A., \& Hafez, E. E. (2010). Biochemical and nutritional characterizations of date palm fruits (Phoenix dactylifera L.). J ApplSci Res, 6(6), 1060-1067.

[9] Ibrahim, S. F., Dalek, N. E. M., Raffie, Q. F. M., \& Ain, M. F. (2020). Quantification of physicochemical and microstructure properties of dark chocolate incorporated with palm sugar and dates as alternative sweetener. Materials Today: Proceedings, 31, 366-371.
[10] Hasan, N. S., Amom, Z. H., Nor, A. I., Norhafizah, M., Norhaizan, M. E., \& Azrina, A. (2010). Nutritional composition and in vitro evaluation of the antioxidant properties of various dates extracts (Phoenix dactylifera L.) from Libya. Asian Journal of Clinical Nutrition, 2(4), 208-214.

[11] Al-Farsi, M. A., \& Lee, C. Y. (2008). Nutritional and functional properties of dates: a review. Critical reviews in food science and nutrition, 48(10), 877-887.

[12] Nasir, M. U., Hussain, S., Jabbar, S., Rashid, F., Khalid, N., \& Mehmood, A. (2015). A review on the nutritional content, functional properties and medicinal potential of dates. Sci. Lett, 3(1), 17-22.

[13] Cheesbrough, M. (2006). District laboratory practice in tropical countries, part 2. Cambridge university press.

[14] Cheesbrough, M. (2000). Microbiological tests. District laboratory practice in tropical countries. Part, 2.

[15] Cheesbrough, M. (2005). Discrete laboratory practice in tropical countries Part 1, Cambridge Second Editions. Published by Press Syndicate of the University of Cambridge, 5, 247-258.

[16] Akoma, O., Agarry, O. O., \& Nkama, I. (2010). Influence of thermal enzymatic hydrolysis of cereal starch on the physico-chemical quality of kunun-zaki (A fermented non-alcoholic cereal beverage). Int $J$ ApplBiol Pharma Technol, 3(1), 821-829.

[17] Ihekoronye, A. I., \& Ngoddy, P. O. (1985). Integrated food science and technology for the tropics. Macmillan.

[18] Jay, M. J. (2005). Microbiological safety of foods. In: Modern Food Microbiology 4th edition, CBS Publishers and Distributors Pvt.Ltd. New Delhi. pp: 641-650.

[19] Gaffa, T., \& Gaffa, A. T. (2004). Microbial succession during "kununzaki" production with sorghum (sorghum bicolor) grains. World Journal of Microbiology and Biotechnology, 20(5), 449-453.

[20] Bede, E. N., Okeke, C. E., \& Amandikwa, C. (2015). Physicochemical Properties and Sensory Evaluation of KunuZaki Beverage Produced by Substitution of Sweet Potatoes with Date Fruits.

[21] Aboh, M. I., \& Oladosu, P. (2014). Microbiological assessment of kunun-zaki marketed in Abuja Municipal Area Council (AMAC) in The Federal Capital Territory (FCT), Nigeria. African Journal of Microbiology Research, 8(15), 1633-1637.

[22] Essien, E. B., Monago, C. C., \& Edor, E. A. (2011). Evaluation of the nutritional and microbiological quality of kunun (a cereal based nonalcoholic beverage) in Rivers State, Nigeria. Internet Journal of Nutrition and Wellness, 10(2).

[23] Amusa, N. A., \& Odunbaku, O. A. (2009). Microbiological and nutritional quality of hawked kunun (a sorghum based non-alcoholic beverage) widely consumed in Nigeria. Pakistan Journal of Nutrition, $8(1), 20-25$.

[24] Egbere, J. O., Odu, C. E., Ngene, A. C., Danladi, M. M., Ohaegbu, C. G., \& Ayika, P. D. (2020). Assessment of the hand hygiene status of internally displaced persons in Jos and environs, Nigeria. African Journal of Microbiology Research, 14(11), 608-616.

[25] Olaoye, O. A., Ubbor, S. C., \& Uduma, E. A. (2016). Determination of vitamins, minerals, and microbial loads of fortified nonalcoholic beverage (kununzaki) produced from millet. Food Science \& Nutrition, 4(1), 96-102.

[26] Egbere, O. J., Pam, K. V., Adesheyan, K. D., A'Kadir, T., \& Oyero, S K. (2009). Effects of pasteurisation on survival patterns of microorganisms and vitamin $\mathrm{C}$ retention in kunun-zaki. African Journal of Biotechnology, 8(23).

[27] Ngene, A. C., Onwuakor, C. E., Aguiyi, J. C., Ifeanyi, V. O., Ohaegbu, C. G., Okwuchukwu, C. P., ... \& Egbere, J. O. (2019). Screening of Some Lactic Acid Bacteria Isolated from Selected Nigerian Fermented Foods for Vitamin Production. Advances in Microbiology, 9(11), 943955.

[28] Umaru, G. A., Tukur, I. S., Akensire, U. A., Adamu, Z., Bello, O. A., Shawulu, A. H., ... \& Adamu, N. B. (2014). Microflora of Kunun-Zaki and Sobo drinks in relation to public health in Jalingo Metropolis, North-Eastern Nigeria. International journal of food research, 1, 1621.

[29] Ngene, A. C., Aguiyi, J. C., Uzal, U., Egbere, J. C., Onyimba, I. A., Umera, A. E., \&Nnadi, N. E. (2020) Bacteriophages as Bio-control agent against Food-Borne Pathogen E. coli O157: H7. IOSR Journal of Pharmacy And Biological Sciences (IOSR-JPBS), Volume 15, Issue 2, PP 23-36.

[30] Oshoma, C. E., Aghimien, M. O., \& Bello, Z. O. (2009). Growth and survival of Escherichia coli in kununzaki during storage. World Journal of Agricultural Sciences, 5(4), 494-497.

[31] Oranusi, S. U., Umoh, V. J., \& Kwaga, J. K. P. (2003). Hazards and critical control points of kunun-zaki, a non-alcoholic beverage in Northern Nigeria. Food Microbiology, 20(1), 127-132. 
[32] Elmahmood, A. M., \& Doughari, J. H. (2007). Microbial quality assessment of kunun-zaki beverage sold in Girei town of Adamawa State, Nigeria. Afr. J. Food Sci, 1(1), 11-15.

[33] Akoma, O., Jiya, E. A., Akumka, D. D., \& Mshelia, E. (2006) Influence of malting on the nutritional characteristics of kunun-zaki. African journal of Biotechnology, 5(10).

[34] El-Sohaimy, S. A., \& Hafez, E. E. (2010). Biochemical and nutritional characterizations of date palm fruits (Phoenix dactylifera L.). J ApplSci Res, 6(6), 1060-1067. 